О. М. Зеленюх, А. Ю.Тимко, М. В. Пинчук

Національна академія Сухопутних військ імені гетьмана Петра Сагайдачного, Львів, Україна

\title{
ОБГРУНТУВАННЯ НАПРЯМКІВ ПІДВИЩЕННЯ ТЕХНІЧНИХ ХАРАКТЕРИСТИК БОЙОВИХ БРОНЬОВАНИХ МАШИН
}

\begin{abstract}
Анотація. В останні роки воєнно-технічна політика технічно-розвинутих країн відрізняється високою динамічністю, гнучкістю, сконцентрованістю на пріоритетних напрямках воєнно-технічного будівництва. Основним її завданням $\epsilon$ створення систем озброєння, що здатні за рахунок якісної переваги забезпечити успішне рішення національними збройними силами бойових завдань 3 можливістю нав'язування противнику в ході бойових дій вигідних для себе форм і способів воєнного протиборства. Бойові дії на Сході України вимагають постійного вдосконалення технічних характеристик зразків озброєння та військової техніки з метою якісної протидії кількісній перевазі збройним силам Російської Федерації та іншим формуванням з нетиповою організаційно-штатною структурою. Великі втрати зразків озброєння та військової техніки Збройних Сил України обумовлюють постійний пошук нових ефективних шляхів підвищення технічних характеристик бойових броньованих машин. В ході проведеного авторами дослідження розглянуто основні напрямки підвищення технічних характеристик бойових броньованих машин. В ході проведеного авторами дослідження використані основні положення протимінної стійкості, теорії живучості та загальнонаукові методи аналізу та синтезу. За результатами проведеного дослідження авторами визначено, що основні напрямки підвищення технічних характеристик бойових броньованих машин направлені на: оптимізацію компонувальних схем; впровадження засобів посилення протимінної стійкості; різні види бронювання 3 використанням сучасних високоміцних матеріалів; впровадження матеріалів і нових технологій, що забезпечують скритність; підвищення мобільності бойових броньованих машин; зменшення маси бойових броньованих машин; зменшення вартості розробки, експлуатації, ремонту та утилізації зразків бойових броньованих машин. Реалізація зазначених напрямків підвищення технічних характеристик бойових броньованих машин дозволить зберегти життя особового складу та дозволить забезпечити виконання поставлених завдань.
\end{abstract}

Ключов і слов а: стандарти, спроможності, НАТО, Збройні Сили України, бойові броньовані машини, живучість, протимінна стійкість.

\section{Вступ}

В останні роки воєнно-технічна політика технічно-розвинутих країн відрізняється високою динамічністю, гнучкістю, сконцентрованістю на пріоритетних напрямках воєнно-технічного будівництва.

Основним iï завданням є створення систем озброєння, що здатні за рахунок якісної переваги забезпечити успішне рішення національними збройними силами бойових завдань 3 можливістю нав'язування противнику в ході бойових дій вигідних для себе форм і способів воєнного протиборства.

Разом $з$ тим, бойові дії на Сході України вимагають постійного вдосконалення технічних характеристик зразків озброєння та військової техніки 3 метою якісної протидії кількісній перевазі збройним силам РФ та іншим формуванням з нетиповою організаційно-штатною структурою [1-3].

Нарощування і оновлення парків бойових броньованих машин (ББМ), включаючи закупівлі, БМП i бойових розвідувальних машин, відбувається в кожному регіоні світу. Сюди входить розробка нових систем, модернізація існуючих систем і закупівля надлишків бойових броньованих машин арміями, що змінюють структуру своїх бронетанкових сил.

Враховуючи зазначене, метою cmammi $є$ обгрунтування напрямків підвищення технічних характеристик бойових броньованих машин.

\section{Виклад основного матеріалу}

Розвиток озброєння ББМ. Завжди було, є i буде бажання підвищити вогневу потужність ББМ. Втім, для ББМ на відміну, наприклад, від зразків бронетанкової техніки або спеціалізованих бойових машин типу протитанкової установки, є більш сильна залежність між розмірами озброєння і іншими необхідними можливостями.

Встановлення автоматичної гармати більшого калібру в минулому вимагало населеної вежі, щоб можна було забезпечити кріплення що відповідає іiі калібру, зберігання боєприпасів та їх подачу. Відповідна за характеристиками прицільна система забезпечувала дальність і точність, необхідні стрілку, і якщо необхідно було одночасно вести пошук цілей, також і командиру [2-4].

Все це означало або одномісну, або двомісну вежу. Населеним баштам необхідний захист, вони займають місце на даху, вони мають “кошика”, що займають внутрішній простір в корпусі. Як наслідок, додавалася маса і зменшувався внутрішній простір. Тому рішення щодо "підвищення вогневої потужності” бойової машини вимагало ретельного проектування і тактичних передумов.

В результаті, більший калібр систем озброєння був обмежений по суті, розвідувальними машинами, яким не потрібно було перевозити багато солдатів, i деякими БМП, які мали меншу десантне відділення.

Сама БМП є визнанням необхідності певного балансу. Це вимагає нелегкого компромісу між оптимізацією для пішого бою і для дій на бойових машинах. Будучи невеликим, піхотне відділення втратило тактичні можливості для окремого маневру, тому тактика підрозділу на БМП спрямована на безпосередню підтримку машини або піхоти, що діє у пішому порядку.

Прийняття компромісу “десант проти калібру гармати” дозволило озброїти БМП 25-мм, 30-мм, 35-мм або навіть 40-мм автоматичними гарматами. 
До технічних інновацій, що змінює цю динаміку проектування, відноситься вдосконалення дистанційно керованих модулів озброєння (ДКМО). У новітніх ДКМО повною мірою використовуються досягнення в оптоелектроніці і відеокамерах 3 тим, щоб встановлювати більш велике озброєння без колишніх обмежень [2-5].

Фактично ДКМО - це зовнішня система по відношенню до машини, оператор розташовується віддалено від модуля, як правило, всередині корпусу.

Озброєння і боєприпаси розміщуються поза корпусом, а прицілювання виконується за допомогою камер високого розширення, що встановлюються разом 3 озброєнням, а вимоги до внутрішнього об'єму обмежені дисплеями стрілка i засобами управління модуля. Немає необхідності проникати в корпус, тому з'являється більше варіантів установки модуля на даху машини.

Перші успішні ДКМО були озброєні крупнокаліберними кулеметами. Модуль Protector норвезької компанії Kongsberg досяг особливого успіху, коли було прийнято рішення про його встановлення на бронетранспортери американської армії Stryker M1126 виробництва General Dynamics.

Переваги цього ДКМО полягають в значному зниженні маси в порівнянні з населеної баштою і здатності вести вогонь по цілях при повному захисті оператора. До недоліків ДКМО відносяться обмежені ситуаційна обізнаність і виявлення цілей і необхідність залишати корпус машини для перезарядження озброєння.

Прогрес в конструкції ДКМО дозволив ББМ отримати переваги дистанційного озброєння з гарматами більшого калібру.

Дебют у 2009 році БМП РUMА розробки РSM (спільне підприємство Krauss-Maffei Wegmann (KMW) i Rhelnmetall) 3 безлюдній 30-мм вежею LANCE, яка йде на зміну БMП MARDER німецької армії, розглядався на той момент деякими як щось незвичайне (рис. 1).

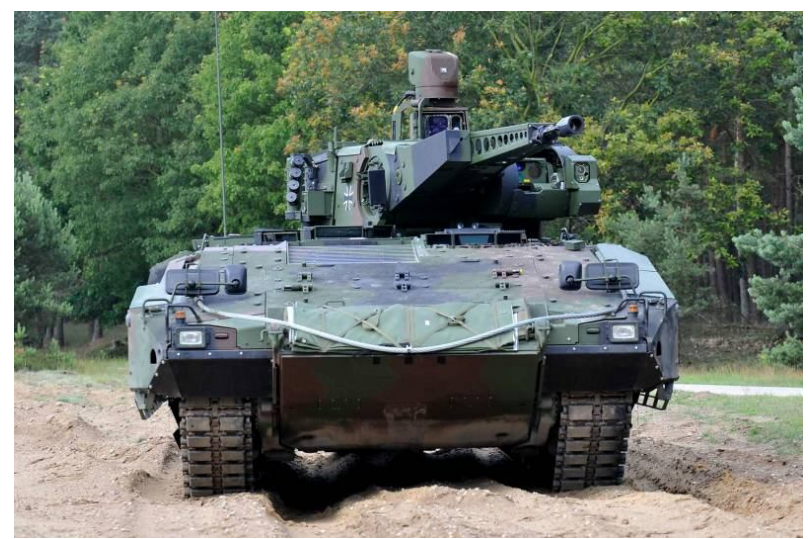

Рис. 1. Зовнішній вигляд башти LANCE 3 30-мм гарматою на німецькій БМП РUMA

Однак, сьогодні в австралійському конкурсі за програмою Land 400 беруть участь машини 3 нежилими вежами. Крім того, в рамках прискореної програми американська армія за активної участі компанії General Dynamics Land Systems розгорнула в 2-му розвідувальному полку, розквартированому в Німеччині, модернізовані бронемашини STRYKER з 30-мм ДКМО MCRWS (Medium Caliber Remote Weapon Station).

Живучість ББМ. Захист, колись синонім броні, в даний час $є$ просто одним 3 інструментів, призначеним для забезпечення живучості зразка (солдата). Багато армій не готові поступитися безпекою особового складу. Живучість $є$ найважливішим фактором, хоча він не повинен підвищуватися за рахунок зменшення мобільності, яка $є$ важливою складовою захисту своїх сил.

Це передбачає виключення або зниження таких факторів, як [1-3]: заброневий розліт осколків; вибухова хвиля; вторинний вплив і навіть предмети, що розлітаються, що підвищують вражаючу дію.

В результаті з'являються рішення, які не тільки протистоять загрозам, але також знижують вражаючі фактори після попадання снаряда чи ракети, тим самим підвищуючи живучість екіпажу і машини. Наприклад, у новій БМП PUMA німецької армії (в даний час пропонується для австралійської програми Land 400) використаний ще один підхід до захисту екіпажу. Командира і стрілка-навідника перемістили в корпус і замінили традиційну жилу башту безлюдною 30-мм вежею LANCE. Це дозволяє зосередитися на підвищенні захисту і живучості шасі, в якому розміщуються екіпаж і десант. Вони в основному покладаються на дані з камер, сенсорів і відеодисплеїв при веденні спостереження і виявлення цілей (рис. 1).

Якість, різноманітність і обсяг інформації, що отримується 3 сенсорів, спрощений обмін нею між системами і членами екіпажу - все це істотно спрощує роботу в пошуково-ударному режимі. Однак, старі підходи змінюються повільно і тепер з'ясовується, що всі кандидати на бойову розвідувальну машину (один 3 трьох типів машин) в рамках програми Land 400 пропонуються 3 двомісної вежею.

Живучість за рахунок систем виявлення. Завдяки новим технологіям живучість ББМ забезпечується тепер не тільки пасивними засобами протидії, а й системами, які борються 3 загрозами за рахунок порушення їх цілевказання. У них використовуються сенсори виявлення наведення, які попереджають оператора про те, що противник намагається прицілитися. Одна $з$ подібних систем використовує приймачі лазерного опромінення, які визначають енергію лазерного випромінювання далекоміра або цілевказання / далекоміра керованого снаряда або ракети. При виявленні сигналу система негайно визначає напрямок, попереджає екіпаж і автоматично або вручну розвертає озброєння в напрямку загрози i запускає димові гранати. Димова завіса закриває обстрілювати машину від ворожого стрілка і порушує канал зв'язку керованої ракети, при цьому відкривається швидкий вогонь у відповідь (рис. 2).

До іншим реагує відповідним засобам протидії відносяться акустичні системи виявлення пострілу, подібні Boomerang III від Raytheon. Вони виявляють вироблений постріл, попереджають оператора і визначають напрямок і відстань до стрільця (рис. 3). 


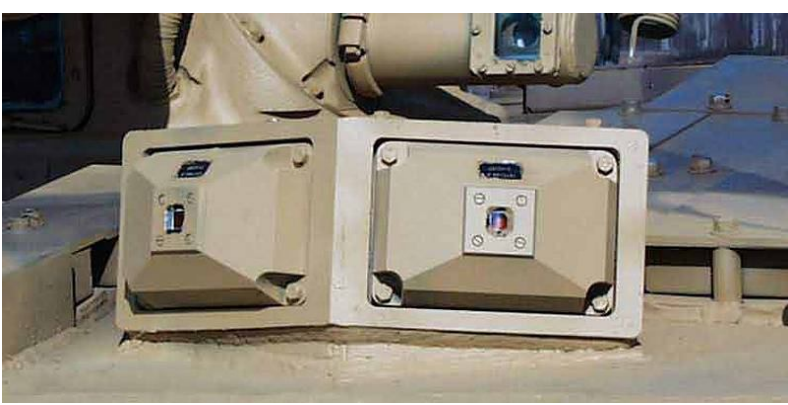

Рис. 2. Система виявлення опромінення ББМ

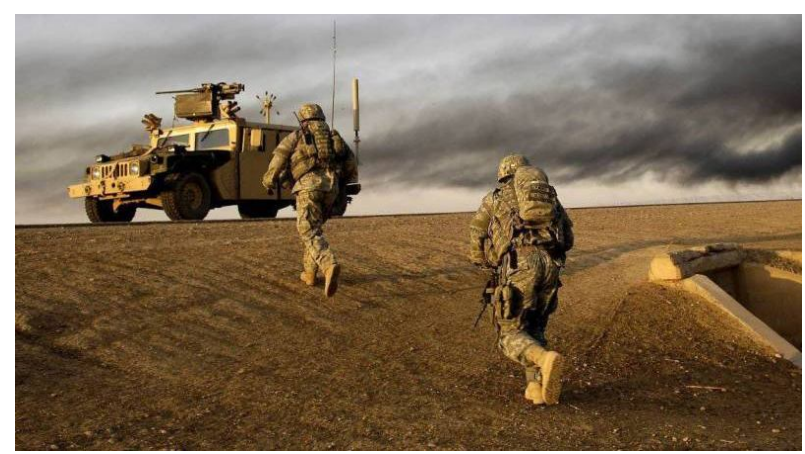

Рис. 3. Акустична система виявлення пострілу Boomerang III, встановлена на бронеавтомобіль HMMWV

Новітні системи, як наприклад EARS від QinetiQ North America, ледь видні на машині. Вони надають напрямок і фізичні координати GPS стрілка. Ця інформація може поширюватися по всьому підрозділу, на більш високі командні рівні і забезпечують вогневі засоби, які можуть накрити вогнем у відповідь. Можна назвати ще одну систему Acoustic Shooter Locating System від Rheinmetall Defense Electronics. Вона автоматично доворачивает ДКМО на виявлену ціль, дозволяючи негайно відповідати ефективним вогнем.

Взаємодія декількох бойових машин підвищує можливості окремих бортових сенсорів, їхню соціальну значимість підвищується за рахунок миттєвого розподілу інформації. В результаті підвищується рівень володіння обстановкою і скорочується час прийняття рішень відкриття вогню у відповідь $[6,7]$.

Ще напрямок використання сенсорів - системи функціонального ураження (soft-kill), до яких відноситься, наприклад, система, що встановлюється на основний бойовий танк українського виробництва “Оплот”. До складу комплексу оптико-електронного подавлення “Варта” входить ІК-глушник, призначений для подавлення атакуючих ракет і цілевказівників керованого озброєння. Система інтегрується 3 датчиками попередження про лазерне опромінювання і пусковими установками аерозольної завіси.

Оптронні глушники також були обрані розробниками російських ББМ і стали встановлюватися ще на початку афганського конфлікту.

За наявною інформацією, вони були встановлені також на кілька нових російських машин. 3 іншого боку, оптико-електронний подавлення не отримало великого поширення на західних ББМ.

Нинішні системи виявлення $є$ в основному реактивними в тому, що вони реагують на дію опонен- та: постріл снайпера або стрілка ініціював процес захоплення цілі і відкриття вогню.

Деякі експерти вважають, що наступним кроком стане впровадження технологій, які завчасно будуть визначати місце розташування і підтверджувати ворожу ціль. Це дозволить машині, перш ніж по ній буде відкритий вогонь, вживати заходів протидії загрозі на власних умовах, а не на умовах машини противника.

В даний час приділяється достатня увага зниження маси автомобіля при збереженні рівня захисту 3 метою підвищення маневреності за рахунок розробки нових міцних легких матеріалів для бронювання. Крім того, в інтересах зниження вартості технічного обслуговування i ремонту, потреби в запасних частинах і скорочення часу на навчання особового складу ремонтних підрозділів конструктори ведуть розробку сімейств машин, що мають до 90\% взаємозамінних вузлів і агрегатів.

Крім підвищення живучості автомобілів військового призначення ведуться науково-дослідні і дослідно конструкторські роботи із забезпечення недопущення виведення з ладу водіїв і екіпажів. У цій області виділилося і швидкими темпами розвивається напрямок по створення роботизованих машин 3 функцією штучного інтелекту.

\section{Висновки}

Таким чином, наведений у статті напрямки підвищення ефективності бойових броньованих машин найближчим часом може бути досягнута наступними заходами:

1) оптимізація компонувальних схем:

застосування модульних конструкцій на базі уніфікованого шасі в залежності від вирішуваних завдань;

зменшення габаритних параметрів автомобіля;

2) впровадження засобів посилення протимінної стійкості:

застосування регульованого кліренсу в сукупності з F-образним, зі збільшеною стійкістю (багатошаровим) днищем;

застосування броньованої капсули;

застосування різних панелей, що поглинають енергію вибуху;

застосування сидінь, які не мають жорсткого зв'язку з підлогою;

3) різні види бронювання з використанням сучасних високоміцних матеріалів:

застосування нетрадиційних броньових матеріалів;

застосування зварного корпусу машини, що складається з окремих броньових листів різної товщини;

застосування оптимальних кутів нахилу броньових листів;

застосування додаткового навісного бронювання з використанням різних екранів і противокумулятивних решіток;

застосування броньовий захисту передньої i бічних частин корпусу, посиленою керамічними плитками; 
застосування броньовий захисту днища кузова, двигуна, трансмісії, роздавальної коробки і паливного бака; застосування броньованих вітрових стекол; застосування броньованого моторного відсіку, винесеного за базу автомобіля;

4) впровадження матеріалів $i$ нових технологій, щзо забезпечують скритність:

застосування маскує фарбування;

застосування різних систем пуску димових (аерозольних) завіс;

зниження помітності в радіо-, ІЧ-і оптичному діапазонах шляхом установки

захисних екранів, захисних фарб, спеціальних

панелей і т. д .; зниження шумності роботи двигуна;

застосування високоефективної системи охолодження випускних газів,

комп'ютерного управління вентиляторами охолодження і турбіною наддуву;

5) підвищення мобільності автомобіля шляхом застосування: сій; гідропневматичних підвісок;

більш потужних двигунів з турбокомпресорами iз змінною геометрією i електронними блоками управління режимом роботи двигуна;

протибуксовочних і антиблокувальних систем, систем управління міжосьовими і міжколесними диференціалами;

гібридних силових установок, електричних приводів коліс, модернізованих систем автоматичного регулювання тиску повітря в шинах, а також боєстійких шин.

6) зменшення маси бойових броньованих маиин.

7) зменшення вартості розробки, експлуатаиії, ремонту та утилізації зразків бойових броньованих машин.

Реалізація зазначений напрямків підвищення живучості автомобільної техніки військового призначення дозволить зберегти життя особового складу та дозволить забезпечити виконання поставлених завдань.

Напрямком подальших досліджень слід вважати розробку методики підвищення протимінної стійкості бойових броньованих машин.

\title{
СПИСОК ЛІТЕРАТУРИ
}

1. Купріненко А. Н., Голуб В. А. Синтез вариантов проектных гипотез технического облика перспективных типов боевых бронированных машин. Військово-технічний збірник. № 2(9). Львів : АСВ, 2013. С. 36-42.

2. Global armoured vehicles market report 2016/ URL: Режим доступу: http://www.defenceiq.com/amouredvehicles/articles/summary-of-global-armoured-vehicle-market-report-2.

3. Купріненко О. М. Обгрунтування принципів формування перспективних типів бойових броньованих машин. Системи озброєння і військова техніка. 2012. № 4(32). С. 40-46.

4. Купріненко А. Н., Голуб В. А. Выбор рационального варианта проектной гипотезы технического облика перспективных типов боевых бронированных машин // Системи озброєння і військова техніка. 2013. № 3(35). С. 24-28.

5. Бісик С. П., Бойко Г. О. Деякі дані сучасного стану й тенденцій розвитку колісних бойових броньованих машин // Озброєння та військова техніка : щокв. наук.-техн. журн. / ЦНДІ ОВТ ЗСУ. 2014. № 3(3). С. 20-24.

6. Кузнецов, Ю. Основные направления развития боевых колесных машин зарубежных стран // Зарубеж. воен. обозрение. - 2013. - № 4. - С. 46-51.

7. Литвиненко А. В., Ткачук Н. А., Литвин Б. Я., Шейко А. И. Общий подход к проектно-технологическому обеспечению защищенности бронекорпусов транспортных средств специального назначения. Механіка та машинобудування. 2012. № 2. C. 221-229.

\section{Justification of directions of improvement of technical characteristics of battle armed machines}

\author{
O. Zelenyukh, A. Tymko, M. Pynchuk
}

Abstract. In recent years, the military-technical policy of the technically-developed countries is characterized by high dynamism, flexibility, and focus on the priority areas of military-technical construction. Its main task is to create weapons systems that are able, through a high-quality advantage, to provide a successful solution to the national armed forces combat missions, with the ability to impose an enemy in the course of combat beneficial forms and methods of military combat. Combat operations in the east of Ukraine require continuous improvement of the technical characteristics of weapons and military equipment in order to qualitatively counter the quantitative advantage of the Russian Armed Forces and other formation with atypical organizational and staff structure. The large losses of weapons and military equipment of the Armed Forces of Ukraine cause a constant search for new effective ways of improving the technical characteristics of armored combat vehicles. In the course of the study, the authors considered the main directions of improving the technical characteristics of armored combat vehicles. In the course of the study, the authors used the main provisions of mine resistance, survivability theory and general scientific methods of analysis and synthesis. According to the results of the study, the authors determined that the main directions of improving the technical characteristics of combat armored vehicles aimed at: optimization of layout schemes; implementation of mine action enhancement; different types of booking using modern high-strength materials; introduction of materials and new technologies that provide secrecy; increasing the mobility of armored combat vehicles; reducing the weight of combat armored vehicles; reducing the cost of developing, operating, repairing and disposing of samples of combat armored vehicles. The implementation of these directions of improving the technical characteristics of combat armored vehicles will save the lives of personnel and will allow to ensure the achievement of the tasks.

Keywords: standards, capabilities, NATO, Armed Forces of Ukraine, armored combat vehicles, survivability, mine resistance. 